Audina N. M. • Y. Maxiselly · S. Rosniawaty

\title{
Pengaruh kerapatan naungan dan frekuensi penyiraman terhadap pertumbuhan bibit kemiri sunan (Reutealis trisperma (Blanco) airy shaw)
}

\section{The effect of shade density and watering frequency on growth of sunan candlenut seeds (Reutealis trisperma (Blanco) airy shaw)}

Diterima : 15 Juli 2016/Disetujui : 10 Agustus 2016 / Dipublikasikan : 30 Agustus 2016

CDepartment of Crop Science, Padjadjaran University

\begin{abstract}
Sunlight intensity and plants watering are the important part in the process of plant growth and development, and also the raw materials of photosynthesis process. This research aims to determine the effect of density shading and watering frequency that most optimal on the growth of Sunan candlenut seeds. This research was conducted at the Ciparanje Experimental field, Jatinangor, Sumedang, West Java with an elevation of \pm 725 meters above the sea levels from November 2015 to January 2016. The design of this research was used a split plot design with 4 replications. The main plot was a shade density treatments that consist of three levels; without shade, shade of $35 \%$ and shade of $25 \%$. The subplots was the watering frequency treatments that consist of three levels; once in a day, once in two days and once in three days. The results showed that there was no interaction between the shade density and watering frequency to the growth of Sunan candlenut seeds. There was no independently effect of shade density, but the best effect of watering frequency independently was once a day seen from the growth component stem diameter, number of leaves, plant height, leaf area index, fresh weight and dry weight of Sunan candlenut seeds.
\end{abstract}

Keywords: Kemiri sunan · Watering frequency . Shade

Sari Intensitas cahaya matahari dan penyiraman tanaman memegang peranan penting dalam proses pertumbuhan dan perkembangan tanaman

\footnotetext{
Dikomunikasikan oleh Fiky Yulianto Wicaksono

Audina N. M. ${ }^{1}$. Y. Maxiselly ${ }^{2}$. S. Rosniawaty ${ }^{2}$

1) Mahasiswa Program Studi Agroteknologi Fakultas

Pertanian Universitas Padjadjaran

2) Dosen Program Studi Agroteknologi Fakultas Pertanian

Universitas Padjadjaran

Korespondensi : yudithia.maxiselly@unpad.ac.id
}

serta merupakan bahan baku proses fotosintesis. Penelitian ini bertujuan untuk mengetahui pengaruh kerapatan naungan dan frekuensi penyiraman yang optimal terhadap pertumbuhan bibit kemiri sunan. Penelitian ini telah dilakukan di kebun percobaan Ciparanje, Jatinangor, Kabupaten Sumedang, Jawa Barat dengan ketinggian tempat \pm 725 meter di atas permukaan laut pada bulan November 2015 sampai Januari 2016. Rancangan yang digunakan adalah rancangan petak terbagi dengan empat ulangan. Petak utama adalah perlakuan kerapatan naungan yang terdiri dari tiga taraf yaitu: tanpa naungan, naungan 35\% dan naungan 25\%. Anak petak adalah perlakuan frekuensi penyiraman yang terdiri dari tiga taraf yaitu: sehari sekali, dua hari sekali dan tiga hari sekali. Hasil penelitian menunjukkan bahwa tidak terdapat interaksi antara kerapatan naungan dengan frekuensi penyiraman terhadap pertumbuhan bibit kemiri sunan. Tidak terdapat pengaruh mandiri terbaik dari faktor kerapatan naungan, namun terdapat pengaruh mendiri terbaik dari faktor frekuensi penyiraman yaitu pada taraf satu hari sekali dilihat dari komponen pertumbuhan diameter batang, jumlah daun, tinggi tanaman, indeks luas daun, bobot basah dan bobot kering kemiri sunan.

Kata kunci : Kemiri sunan · Frekuensi penyiraman $\cdot$ Naungan

\section{Pendahuluan}

Krisis energi berupa minyak bumi sudah melanda dunia sehingga banyak negara memikirkan jalan keluar dalam mengatasi krisis tersebut yang semakin lama semakin meningkat. Cadangan minyak dunia yang tersisa adalah sebesar 3.356,8 milyar barel dan hanya akan mampu memenuhi kebutuhan minyak selama 80-100 tahun (OPEC, 2008). 
Kemiri Sunan (Reutealis trisperma (BLANCO) Airy Shaw) merupakan tanaman penghasil bahan bakar nabati yang tergolong baru dikembangkan di Indonesia. Kandungan asam lemak biji kemiri sunan yang paling banyak jumlahnya adalah kandungan asam aoleostearat yang menyebabkan kemiri sunan sangat beracun sehingga tidak dapat dikonsumsi (Sudrajat, 1983). Biji kemiri sunan yang menjadi organ target tanaman ini memiliki rendemen minyak sebesar $50 \%$ dan tidak bersaing dengan kebutuhan pangan (Herman dan Pranowo, 2009), namun potensi tersebut belum banyak diketahui oleh khalayak untuk dimanfaatkan.

Budidaya kemiri sunan dimulai dari tahap pembibitan. Fase pembibitan tergolong penting dalam budidaya kemiri sunan. Pembibitan memerlukan kegiatan pengelolaan yang baik karena bibit dapat menentukan hasil akhir dari suatu tanaman. Fase tersebut menentukan produksi tanaman perhektarnya dalam kurun waktu yang relatif lama mengingat tanaman ini tergolong tanaman tahunan.

Pertumbuhan dan perkembangan tanaman di fase pembibitan dipengaruhi oleh intensitas cahaya, begitu juga dengan kemiri sunan. Intensitas cahaya mempengaruhi laju fotosin-tesis yang terjadi dalam tanaman. Pada umur tanaman yang tergolong muda, intensitas cahaya yang dibutuhkan masih tergolong rendah sampai tanaman menjelang dewasa dengan kebutuhan cahaya yang lebih tinggi (Suhardi 1995 ; Faridah, 1996). Masing-masing tanaman memiliki tingkat respon yang berbeda terhadap intensitas cahaya matahari yang diterimanya. Air sangat penting peranannya sebagai bahan baku proses fotosintesis tanaman. Apabila tanaman mendapatkan asupan air yang minimum maka stomata daun akan menutup sehingga dalam proses masuknya $\mathrm{CO}^{2}$ akan terhambat sehingga akan mempengaruhi aktifitas fotosintesis dan menghambat proses sintesis protein dan juga dinding sel (Salisbury dan Ross, 1995).

Penelitian ini bertujuan untuk mengetahui pengaruh interaksi kerapatan naungan dan frekuensi penyiraman yang optimal terhadap pertumbuhan bibit kemiri sunan (Reutealis trisperma (BLANCO) Airy Shaw).

\section{Bahan dan Metode}

Percobaan dilakukan di kebun percobaan Ciparanje Fakultas Pertanian Universitas Padja- djaran, Jatinangor, Kabupaten Sumedang, Jawa Barat dengan ketinggian tempat \pm 725 meter di atas permukaan laut dan ordo Inceptisols, tipe curah hujan $\mathrm{C}$ menurut klasifikasi iklim Schmidt-Ferguson (1951). Percobaan dilaksanakan dari bulan November 2015-Januari 2016.

Bahan yang digunakan pada percobaan ini adalah bibit kemiri sunan varietas Kemiri Sunan-2 berumur lima bulan dari Balai Pengembangan Benih Tanaman Perkebunan (BPBTP) BandungJawa Barat, pupuk Urea, pupuk SP-36, pupuk KCl dan fungisida dengan bahan aktif Mankozeb 80\%.

Alat yang digunakan adalah timbangan analitik, meteran, alat tulis, jangka sorong, leaf area meter, lux meter, cangkul, ember, pisau, termometer, higrometer, paranet dengan pengaturan naungan $25 \%$ dan $35 \%$, plastik transparan, oven listrik, jaring penangkap serangga, kamera, papan perlakuan, bambu untuk tiang paranet dan tali rafia.

Rancangan percobaan yang digunakan adalah Rancangan Petak Terbagi (Split Plot Design). Perlakuan terdiri dari dua faktor yaitu petak utama dan anak petak. Faktor petak utamanya adalah kerapatan naungan yang terdiri dari tiga taraf yaitu: tanpa naungan, naungan 35\%, dan naungan 25\%. Faktor anak petak adalah frekuensi penyiraman yang terdiri dari tiga taraf yaitu : satu hari sekali, dua hari sekali, dan tiga hari sekali.

Pelaksanaan percobaan meliputi seleksi bibit yang seragam, tidak terserang hama dan penyakit serta memiliki jumlah daun 5-6 helai yang berasal dari Balai Pengembangan Benih Tanaman Perkebunan (BPBTP) menggunakan media tanam top soil dengan ordo tanah Andisol, pasir, dan kompos kotoran sapi dengan perbandingan 1:1:1. Bibit diletakkan di bawah naungan dengan jarak antar polibeg $30 \mathrm{~cm} \times 30 \mathrm{~cm}$.

Perlakuan naungan menggunakan paranet dengan pengaturan naungan $25 \%, 35 \%$ dan tanpa naungan. Naungan dibuat menutupi seluruh permukaan barisan polybag dengan bambu sebagai tiang penyangga paranet. Frekuensi penyiraman dilakukan sesuai dengan perlakuan yang diuji. Volume air yang digunakan adalah hasil dari uji kapasitas lapang.

Pemeliharaan tanaman meliputi penyiangan gulma dan pengendalian hama serta penyakit secara manual. Pemupukan tanaman dilakukan dengan menggunakan pupuk Urea dengan dosis $15 \mathrm{~g} /$ tanaman, SP-36 dengan dosis $20 \mathrm{~g} /$ tanaman dan $\mathrm{KCl}$ dengan dosis 15 g/tanaman (Pranowo, 2009). Pemupukan dilakukan setiap satu bulan sekali dengan cara membuat 3 lubang di sekitar tanaman. 
Pengamatan penunjang meliputi kondisi lingkungan percobaan dan analisis tanah awal sebelum percobaan. Pengamatan utama dilakukan pada umur bibit tiga bulan setelah perlakuan. Parameter yang diamati adalah pertambahan diameter batang, pertambahan jumlah daun, pertambahan tinggi bibit, indeks luas daun, bobot segar dan bobot kering diamati pada saat bibit berumur 3 bulan setelah perlakuan atau bibit usia 8 bulan setelah tanam.

\section{Hasil dan Pembahasan}

Hasil analisis ragam menunjukkan tidak terjadi pengaruh interaksi antara kerapatan naungan dengan frekuensi penyiraman terhadap pertambahan tinggi, jumlah daun, diameter batang, indeks luas daun, bobot basah dan bobot kering bibit kemiri sunan. Tidak terdapat perbedaan dari faktor kerapatan naungan secara mandiri, namun terdapat pengaruh mandiri dari perlakuan frekuensi penyiraman umur bibit 8 bulan yang ditunjukkan pada Tabel 1 .

Kerapatan Naungan. Perlakuan kerapatan naungan memberikan pengaruh yang tidak berbeda nyata terhadap pertambahan diameter batang, tinggi bibit, jumlah daun, indeks luas daun, bobot basah dan bobot kering kemiri sunan pada umur 8 bulan.

Perlakuan kerapatan naungan memberikan pengaruh yang tidak berbeda nyata pada semua pengamatan, hal tersebut diduga karena umur bibit yang sudah cukup dewasa sehingga respon fisiologi yang diterima tanaman cenderung sama dan siap dipindahkan ke lapangan dengan ciri-ciri jumlah daun sudah lebih dari 10 helai. Hal ini juga menunjukkan bibit kemiri sunan berumur 5-8 bulan dapat tumbuh baik pada lingkungan dengan intensitas cahaya matahari penuh, sehingga penggunaan naungan dapat dikurangi secara bertahap seiring dengan bertambahnya umur hingga bibit pindah lapang.

Faridah (1996) menyatakan bahwa tanaman yang berumur muda pada umumnya memerlukan cahaya dengan intensitas yang relatif rendah dan seterusnya menjelang dewasa mulai memerlukan cahaya dengan intensitas yang lebih tinggi untuk mendapatkan hasil yang optimum. Ferita dkk. (2009) menyatakan bahwa tidak berbedanya pengaruh beberapa intensitas cahaya terhadap tinggi bibit gambir disebabkan tanaman gambir merupakan tanaman tahunan yang memiliki fase vegetatif yang lambat dan tidak memacu tinggi tanaman walaupun diberikan intensitas cahaya yang tinggi. Penelitian mengenai tanaman pulai (Alstonia scholaris) berumur 6 bulan pada level naungan $0 \%$ dan $25 \%$ memberikan hasil yang tidak berbeda nyata pada variabel pengamatan bobot kering dan bobot basah tajuk (Juhaeti, 2009).

Frekuensi Penyiraman. Perlakuan penyiraman yang paling baik terdapat pada frekuensi satu hari sekali. Penyiraman satu hari sekali memberikan kondisi air yang masih tersedia untuk tanaman. Hal yang sama terjadi pada fase pembibitan main nursery bibit kelapa sawit pada pengamatan 2 MST sampai dengan 12 MST menunjukkan bahwa penyiraman sehari sekali dapat meningkatkan diameter batang yang lebih besar dibandingkan dengan penyiraman dua hari sekali dan tiga hari sekali (Hermanto dkk., 2014).

Tabel 1. Pengaruh Kerapatan Naungan dan Frekuensi Penyiraman terhadap Pertumbuhan Kemiri Sunan Umur 8 Bulan.

\begin{tabular}{clccccc}
\hline \hline Perlakuan & $\begin{array}{c}\text { Pertambahan } \\
\text { Tinggi Bibit } \\
(\mathrm{cm})\end{array}$ & $\begin{array}{c}\text { Pertambahan } \\
\text { Jumlah Daun } \\
(\text { Helai) }\end{array}$ & $\begin{array}{c}\text { Pertambahan } \\
\text { Diameter } \\
\text { Batang }(\mathrm{cm})\end{array}$ & $\begin{array}{c}\text { Indeks } \\
\text { Luas Daun }\end{array}$ & $\begin{array}{c}\text { Bobot } \\
\text { Basah }(\mathrm{g})\end{array}$ & $\begin{array}{c}\text { Bobot } \\
\text { Kering }(\mathrm{g})\end{array}$ \\
\hline \multicolumn{7}{c}{ Kerapatan Naungan } \\
\hline Tanpa Naungan & 8,97 & 5,50 & 4,54 & 24,60 & 81,81 & 27,91 \\
$35 \%$ & 8,60 & 5,58 & 4,48 & 21,76 & 77,22 & 26,31 \\
$25 \%$ & 8,53 & 5,39 & 4,40 & 21,95 & 75,28 & 25,46 \\
\hline Sehari Sekali & $11,39 \mathrm{c}$ & $7,89 \mathrm{c}$ & $5,93 \mathrm{c}$ & $27,32 \mathrm{~b}$ & $107,36 \mathrm{c}$ & $35,90 \mathrm{c}$ \\
Dua Hari Sekali & $9,58 \mathrm{~b}$ & $5,56 \mathrm{~b}$ & $4,60 \mathrm{~b}$ & $22,77 \mathrm{ab}$ & $79,72 \mathrm{~b}$ & $27,50 \mathrm{~b}$ \\
Tiga Hari Sekali & $5,13 \mathrm{a}$ & $3,03 \mathrm{a}$ & $2,89 \mathrm{a}$ & $18,22 \mathrm{a}$ & $47,22 \mathrm{a}$ & $16,29 \mathrm{a}$ \\
\hline \hline
\end{tabular}

Keterangan:

- Angka yang tidak diikuti dengan huruf menyatakan tidak berbeda nyata menurut Uji Beda Nyata Terkecil pada taraf $5 \%$.

- Angka yang diikuti dengan huruf yang berbeda menunjukkan hasil yang berbeda nyata menurut Uji Beda Nyata Terkecil pada taraf $5 \%$. 
Kelebihan air bagi pertumbuhan tanaman akan menyebabkan sel-sel menjadi tumbuh secara optimal karena tekanan turgor sel meningkat disebabkan sel tumbuhan terisi penuh oleh air (Astuti dan Darmanti, 2010). Siregar dkk. (1992) menyarankan pemberian air pada media pembibitan dilakukan satu hari sekali untuk tanaman kakao.

Asupan air yang cukup akan mempengaruhi pertumbuhan dan perkembangan suatu tanaman. Bibit sengon laut (Paraserianthes falcataria, L.) dengan frekuensi penyiraman satu hari sekali memiliki permukaan daun yang lebih luas, akar yang paling panjang, bobot tajuk dan bahan kering yang lebih berat (Tefa dkk., 2015). Penyiraman dua hari sekali memiliki pertumbuhan tanaman yang lebih baik dibandingkan dengan penyiraman tiga kali, hal ini menunjukkan kemiri sunan masih mampu beradaptasi pada penyiraman dua hari sekali pada fase pembibitan akhir.

\section{Kesimpulan}

1. Tidak terdapat interaksi antara kerapatan naungan dengan frekuensi penyiraman terhadap pertumbuhan bibit kemiri sunan (Reutealis trisperma (BLANCO) Airy Shaw).

2. Tidak terdapat pengaruh mandiri terbaik dari faktor kerapatan naungan, namun terdapat pengaruh mandiri terbaik dari faktor penyiraman yaitu pada taraf satu hari sekali.

\section{Daftar Pustaka}

Astuti, T. dan S. Darmanti. 2010. Perkembangan serat batang Rosella (Hibicus sabdariffa var. Sabdariffa) dengan perlakuan naungan dan volume penyiraman yang berbeda. Buletin Anatomi dan Fisiologi. Vol. XVIII, No. 2. Universitas Diponegoro. Semarang.

Faridah, E. 1996. Pengaruh intensitas cahaya, mikoriza dan serbuk arang pada pertumbuhan alam Rybalanops Sp. Buletin Penelitian, Fahutan UGM Yogyakarta, 29 : 21-28.

Ferita, I., A. Nasrez., F. Hamda., dan S. Erni. 2009. Pengaruh intensitas cahaya terhadap pertumbuhan bibit gambir (Uncaria gambir
Roxb.). Buletin. Universitas Andalas. Padang.

Herman, M. dan D. Pranowo. 2009. Kemiri sunan untuk konservasi tanah dan air. Sirkuler teknologi tanaman rempah dan industri. Balai Penelitian Tanaman Rempah dan Aneka Tanaman Industri. 15p.

Hermanto., F. E. Sitepu dan J. Ginting. 2014. Pertumbuhan bibit kelapa sawit (Elaesis guineensis Jacq.) dengan menggunakan media sekam padi dan frekuensi penyiraman di main nursery. Jurnal Online Agroteknologi Vol. 2 No. 3 : 1211-1218. Universitas Sumatra Utara. Sumatra.

Juhaeti, T. 2009. Pengaruh naungan terhadap pertumbuhan bibit pulai (Alstonia scholaris (L.) R.Br). Buletin Pusat Penelitian BiologiLIPI Vol.9 No.6. Bogor.

OPEC. 2008. World Oil Outlook 2008. OPEC Secretariat, Vienna

Pranowo, D. 2009. Bunga rampai kemiri sunan penghasil biodiesel, solusi masalah energi masa depan. Teknologi perbenihan. Balai Penelitian Tanaman Rempah dan Aneka Tanaman industri. Hal 97-104.

Salisbury, F.B dan C.W Ross. 1995. Fisiologi Tumbuhan Jilid 3. Penerbit ITB: Bandung.

Schmidt, F.H., and J.H.A. Ferguson. 1951. Rainfall type based on wet and dry period ratio for Indonesia with Western New Gurinea. Kementerian Perhubungan. Jawatan Meteorologi dan Geofisika. Jakarta.

Siregar, T. H. S., S. Riyadi dan L. Nuraeni. 1992. Budidaya pengolahan dan pemasaran cokelat. Penebar Swadaya. Jakarta. 170 hal.

Sudrajat, 1983. Sifat fisiko kimia hasil hutan bagian I. Laporan No. 164. Balai Penelitian dan Pengembangan Hasil Hutan. Bogor.

Suhardi, 1995. Effect of shading, mycorrizha inoculated and organic matter on the growth of Hopea gregaria seedling. Buletin Penelitian Fahutan UGM Yogyakarta, 28 : 18-27.

Tefa, P., M. Roberto., Taolin dan A. Lelang. 2015. Pengaruh dosis kompos dan frekuensi penyiraman pada pertumbuhan bibit sengon laut (Paraserianthes falcataria, L.). Jurnal Pertanian Konservasi Lahan Kering. Savana Cendana Vol 1. 13-16. Universitas Timor. Nusa Tenggara Timur. 